\title{
Tourist Preferences and Cost Efficiency of International Tourist Hotels in Taiwan
}

\author{
Hwai-Shuh Shieh ${ }^{1}$, Jin-Li Hu ${ }^{2} \&$ Li-Ying Gao ${ }^{2}$ \\ ${ }^{1}$ Department of Tourism and Hospitality Management, Kainan University, Taiwan \\ ${ }^{2}$ Institute of Business and Management, National Chiao Tung University, Taiwan \\ Correspondence: Jin-Li Hu, Institute of Business and Management, National Chiao Tung University, No. 118, \\ Chung-Hsiao W. Rd., Sec. 1, Taipei City 100, Taiwan. Tel: 886-2-2381-2386. E-mail: jinlihu@gmail.com
}

Received: February 20, 2014 Accepted: March 17, 2014 Online Published: May 21, 2014

doi:10.5539/ijms.v6n3p35

URL: http://dx.doi.org/10.5539/ijms.v6n3p35

\begin{abstract}
This paper analyzes the effects of tourist nationality sources on international tourist hotels' (ITHs) cost efficiency in Taiwan and the factors affecting a tourist's choice of a hotel. The data envelopment analysis (DEA) approach is used to compute cost efficiency scores of 61 ITHs in Taiwan during 1998-2007. The number of Asian, North American, Japanese, and local tourists has significantly positive effects on cost efficiency, but the number of overseas Chinese has a negative effect on cost efficiency. The number of tourists of other nationalities has no influence on cost efficiency. Generally, most tourists in Taiwan prefer a larger, older, and closer-to-airport hotel. This study also finds that the chain system, the number of scenic spots surrounding hotels, and the ratio of individual tourists all significantly improve the cost efficiency of ITHs in Taiwan.
\end{abstract}

Keywords: tourist preferences, nationality sources, cost efficiency, scenic spots, international tourist hotel

\section{Introduction}

The demand for recreational traveling has increased quickly as local people's income as well as the number of foreign visitors increase all over the world. According to the prediction of World Tourism Organization (UNWTO), the average annual growth rate of tourists from 1995 to 2020 is $6.5 \%$ in East Asia, which is the second highest growth rate in the world. The Asia-Pacific market is forecasted to grow from 195 million person-visits in 2010 to 397 million in 2020. The tourism industry not only brings in huge foreign exchange income, but also provides job opportunities in the tourism sector as well as many other industries. According to the World Travel \& Tourism Council (WTTC), global tourism expenditures will increase from USD 4.21 trillion to USD 8.61 trillion. Moreover, the total contribution of travel and tourism to global employment, including jobs indirectly supported by the industry, is forecast to rise by $2.3 \%$ per annum from $258,592,000$ jobs $(8.8 \%$ of total employment) in 2011 to 323,826,000 jobs (9.7\% of total employment) by 2021 .

Taiwan's global travel and tourism competitiveness ranking moved up to 43rd in 2009 from 52nd in 2008, according to the latest survey report released by the World Economic Forum (WEF). The WEF-drawn Global Competitiveness Rankings are based on the Travel and Tourism Competitiveness Index (TTCI) and covers 133 economies around the world. Taiwan placed ninth in the TTCI's Asia-Pacific rankings, trailing behind Australia, Singapore, Hong Kong, New Zealand, Japan, South Korea, Malaysia, and Thailand, but placed one notch ahead of China. Taiwan's higher TTCI global ranking in 2009 could be attributed to its increased number of hotel rooms and car rentals as well as a surge in its creative industries' exports. However, despite an improved ranking in 2009, Taiwan fell far short of the 30th place it held in 2007 when the WEF released TTCI rankings for the first time. Taiwan's major competitors include China, which moved up in the 2009 rankings to 47 th from $62 \mathrm{nd}$ in 2008, and South Korea, which remained in the 31 st spot.

In Taiwan the number of visitor arrivals increased by about 2.74 million from 2001 to 2010. The grand total of foreign exchange in Taiwan's tourism industry has grown from USD 3.991 billion in 2001 to USD 6.816 billion in 2009. As the same time, the demand for accommodations in Taiwan has also risen quickly. The number of ITHs rose from 44 hotels in 1985 to 70 hotels in 2011. As the hotel is one of the most important industries in Taiwan, it is worth paying more attention to the evaluation of hotel operation efficiency, which intensifies 
competition in hospitality industries. Facing increasingly fierce competition, how to enhance productivity and use resources more effectively are now critical issues for hoteliers.

The number of foreign visitors to Taiwan has also been increasing continuously. According to statistics of the Taiwan Tourism Bureau (TTB), the number of visitor arrivals hit 5,567,277 in 2010, or 26.67\% higher than the previous year, with the four main residences of the visitors being mainland China, Japan, Hong Kong \& Macao, and the U.S. Compared with 2009, mainland China has replaced Japan to send the largest number of visitors to Taiwan. Due to the signing of the 'Economic Cooperation Framework Agreement' (ECFA) between Taiwan and mainland China, the tourism policy of openness across the Taiwan Strait will surely attract more and more Chinese tourists to visit Taiwan.

Because foreign visitors come from different countries or regions, an interesting issue emerges - that is, whether the different nationalities affect ITHs' managerial efficiency or not. Hwang \& Chang (2003) find that ITHs in Taiwan whose customers are mainly foreigners achieve better efficiency than those only servicing local customers. Based on their study, we are interested in understanding which nationality has a stronger effect upon hotel managerial efficiency, or whether there are no differences among all these nationalities. If tourists' nationality does affect the managerial efficiency, then we will further look into what factors of tourists' preferences impact their ITH choice.

\section{Literature Review}

\subsection{DEA Approach}

The efficiency measure was originated by Farrell (1957) and two primary categories of approach can be applied to evaluate efficiency: the data envelopment analysis (DEA) approach and the stochastic frontier approach (SFA) Most studies have adopted the DEA approach to evaluate efficiency, as it uses a mathematical programming model to calculate the best multiplier for inputs and outputs (Charnes et al., 2009). DEA can measure the relative efficiency of decision-making units (DMUs) as part of a collection of DMUs that utilize similar resources and/or inputs in order to produce similar goods or service outputs. This method is accepted by most people, because it can evaluate efficiency for different periods. SFA uses econometric methods first adopted by Aigner, Lovell, \& Schmidt (1977) and Meeusen \& van den Broeck (1977) simultaneously.

DEA is basically a non-parametric technique in operational research and economics for the estimation of production frontiers. Non-parametric approaches have the benefit of not assuming a particular functional form for the frontier. Farrell was the pioneer in dividing cost efficiency into technical efficiency and allocative efficiency.

DEA has been widely applied in many different fields. In the hotel industry, previous studies that used DEA to investigate the relative efficiency between different hotels are now described as follows: Morey \& Dittman (1995) analyzed the operational efficiency of 54 tourist hotels in the U.S. by DEA. The input variables included room division expenditure, energy costs, salaries, non-salary expenses for property, related expenses for variable advertising, non-salary expenses for variable advertising, fixed market expenditures, payroll and related expenses for administrative work, and non-salary expenses for administrative work, while the output variables included total revenue, level of service delivered, market share, and rate of growth. The results showed that the operational efficiency of a hotel is $89 \%$, which means the hotel industry is efficient.

Anderson et al. (1999) investigated the operational efficiency of 48 tourist hotels in the U.S. in 1994 through SFA and DEA. The input variables included the number of employees, the number of rooms, casino and entertainment expenditures, and food expenditure and other expenditure, while the output variables included income from rooms, income from casino and entertainment, and income from food and others. The results showed that the average efficiency of 48 tourist hotels is up to $89.4 \%$ when using DEA, whereas it is $94.6 \%$ when using SFA.

\subsection{Hotels' Efficiency in Taiwan}

The literature applying DEA to compute the efficiency of Taiwan's hotel industry includes Tsaur (2001), Chang (2003), Chiang et al. (2004), Yang \& Lu (2006), Hung et al. (2006), Hu et al. (2009), Chen et al. (2010), and Shieh (2012). Some studies have adopted SFA to evaluate the efficiency of Taiwan's hotel industry, such as Chen (2007) and Hu et al. (2010). We summarize these papers as follows.

Tsaur (2001) used DEA to evaluate the operating efficiency of 53 international tourist hotels (ITHs) in Taiwan during 1996-1998. The result indicated that the average operating efficiency score is $87.33 \%$, which implies that managers on average could reduce their input costs by $12.67 \%$ if they operated on the efficient frontier. The DEA results showed that the hotel industry in Taiwan is operating efficiently. However, $71.7 \%$ of the ITHs in 
Taiwan reveal relative inefficiency. In other words, almost three out of four hotels are considered to be relatively inefficient, underscoring the fact that operating efficiency needs to be reinforced. He also found that the catering department performs better than the accommodations department.

Hwang and Chang (2003) analyzed the efficiency of ITHs in Taiwan and the change of efficiency in 1994-1998 by DEA and the Malmquist productivity index. They found that the operational efficiency between hotels is obviously different, due to types of market, customer sources, and operational type.

Chiang and Wang (2004) also adopted DEA to analyze the four-star and five-star hotels in Taipei. The input variables were number of hotel rooms, capacity of food and beverage, number of employees, and the total costs of the hotel. The output variables were yielding index, the revenue from food and beverage, and miscellaneous revenue. They compared three different operational types: independently owned and operated, franchise licensed, and internationally managed. Their result showed that not all of Taipei's franchised or managed ITHs perform more efficiently than the independent ones.

Yang and Lu (2006) explored 56 ITHs' managerial performance in Taiwan by DEA in 2002. Their findings indicated the mean technical efficiency is $84.80 \%$, which can be divided into pure technical efficiency and scale efficiency with means 0.876 and 0.969 , respectively. Therefore, scale efficiency is relatively lower. The inefficiency of these hotels was composed of excess rooms and catering floors, or employing too many workers in the accommodation and catering departments. This study also found that the relative efficiency of those ITHs located in scenic areas is higher than those in cities.

Hung et al. (2006) studied the relative efficiency of ITHs in Taiwan, using five different measures: overall efficiency (OE), allocative efficiency (AE), technical efficiency (TE), scale efficiency (SE), and pure technical efficiency (PTE). The result indicated these ITHs in Taiwan are inefficient. The largest efficiency losses are attributed to technical inefficiencies, of which scale inefficiencies are the primary cause. Because the scale of hotels in Taiwan is too small, the managers could not reduce costs by large-scale operations. The Tobit regression results indicated that the proportions of foreign individual travelers, online transaction functions and franchising are beneficial to the operation efficiency of ITHs in Taiwan.

Chen (2007) adopted SFA to analyze the operational performance of 55 ITHs in Taiwan in 2002. The results showed that the average efficiency of ITHs is $80 \%$ and presented no relationship between efficiency and the location or scale of hotels. However, the operational performances of chain hotels are better than independent hotels.

$\mathrm{Hu}$ et al. (2009) investigated cost, allocative, and overall technical efficiencies of ITHs in Taiwan during 1997-2006, using three input variables, three output variables, and three input price variables. There were four environmental variables in this study: type of location, type of operation, distance to nearest international airport, and the occupancy rate. The main findings of this study are that the chain system, non-metropolitan areas, and the occupancy rate have significantly positive impacts on all efficiency scores of Taiwan's ITHs. However, the distance from the nearest international airport has significantly negative impacts on efficiency scores.

Assaf et al. (2010) used a new method, the metafrontier, to estimate separate production frontiers for different groups of firms to evaluate 78 ITHs in Taiwan. The results indicated that a large size and the chain operation of a particular hotel induce significantly better efficiency scores.

$\mathrm{Hu}$ et al. (2010) used the one-stage stochastic frontier approach (SFA) with three outputs, three inputs and five environmental variables to simultaneously estimate cost efficiency scores and factors of cost inefficiency for 66 international tourist hotels in Taiwan during 1997-2006. Their results show that international tourist hotels in Taiwan are on average operating at $91.15 \%$ cost efficiency. Chain systems, tourist guides, and international transportation can significantly improve the cost efficiency of international tourist hotels in Taiwan.

Chen et al. (2010) analyzed the effects of tourist nationalities on the cost efficiency of ITHs in Taiwan during 1996 to 2007. The input variables were number of guest rooms, number of employees, and total floor space of the catering division. The output variables included total revenues from food and beverage (F\&B), total revenues from rooms, and other revenues. The number of tourists by nationally was one of the environmental variables, which was a new idea in the hotel industry. The study showed that the numbers of local Taiwanese, North American, Japanese, and Australian tourists increase the cost efficiency of ITHs in Taiwan, whereas the numbers of other Asian tourists (including mainland China) have no significant effects on cost efficiency.

Shieh (2012) investigated the link between 'green' and cost efficiency in the hotel industry in Taiwan. Empirical evidence indicated that 'green' renders a hotel ineffective. 


\subsection{Tourists' Preference}

In addition to evaluating the cost efficiency of ITHs in Taiwan, we also pay attention to what services a hotel supplies will affect different nationality customers' decision in hotel selection. For example, Saleh \& Ryan (1992) collected a sample of 145 guests in a western Canadian city and indicated that the restaurant availability, convenient parking, interior décor, and exterior aesthetics help attract guests. Tourist preference is thus the act of selecting from among a set of choices as influenced by one's motivations (Tran \& Ralston, 2006). According to Tarasewich (1996), a company must focus on its customers to find a way to stand out among competitors.

Although tourist attractions are fundamental to the very existence of tourism, Lew (1987) indicates that tourist preference is one of the cross-perspective measures which can be applied to typologies based on any of the three perspectives: the ideographic listing, the organization, and the tourist cognition of attractions. At the same time, in his study, all three perspectives make comparisons based on the historical, locational, and various valuational aspects of attractions.

In the Pizam \& Sussmann's (1995) study, their results indicated that in 18 out of 20 behavioral characteristics there was a significant perceived difference between the four nationalities including Japanese, French, Italian, and American. Tour guides perceived the Japanese to be the most unique among the four, and the Italians as the most similar to others. A pair-comparison found the Italians and French to be perceived as the most similar to each other. The least similar were perceived to be the French-American pair.

Lehto et al. (2004) examined tourists' shopping preferences and behaviors in relation to their socio-demographic characteristics and trip attributes by using data from the 1999 Survey of Taiwanese Outbound Travellers. Their results indicated that travel purpose, travel style, age and gender were significant factors influencing the amount of money travellers spent on shopping and the items that they preferred to buy.

Cai et al. (2004) suggested the need to expand the discussion of the subject more on the tourist preference towards information contents than on the information channels.

Hsu et al. (2009) used a 4-level AHP model, consisting of 22 attributes, to identify the factors that influence the tourists' choice of destination and evaluates the preferences of tourists for destinations. Their results point out that visiting friends/relatives and personal safety appear to be the 2 most important factors for inbound tourists to Taiwan.

Chen et al. (2011) took into account the hotel product variety as one of the environmental factors (which also include the minimum distance from the hotel to the nearest international airport, management type, location, and geographical areas) and hotel characteristics (i.e., swimming pool, business center, gym, and shuttle services). Therefore, we will study the product variety among hotels and whether they affect the hotel selection of different nationality tourists.

\subsection{Summary of Past Studies}

Past studies on evaluating the performance in Taiwan's hotel industry use various input and output items. As Table 1 shows, most inputs entail the number of rooms, number of full-time equivalent employees, expenses about operations, and total floor space of the catering division. Most outputs include revenue from room, F\&B, and others. Several topics are discussed there in. For example, what type of operation is more efficient in the hotel industry (e.g., Tsaur, 2001; Hwang \& Chang, 2003; Yang \& Lu, 2006; Hu et al., 2010; Chen et al., 2010; $\mathrm{Hu}$ et al., 2013). Most have found that chain-operated hotels are more efficient than independent hotels. The scale of hotels has also been discussed in past research studies (e.g., Hwang \& Chang, 2003; Chen, 2007), with results showing that the scale of rooms has no positive relationship with the efficiency scores. 
Table 1. Recapitulation of studies on hotel frontier efficiency

\begin{tabular}{|c|c|c|c|c|}
\hline Authors & Method & Units & Inputs & Outputs \\
\hline $\begin{array}{l}\text { Morey \& } \\
\text { Dittman (1995) }\end{array}$ & DEA & $\begin{array}{l}54 \text { U.S. tourist } \\
\text { hotels, } 1995\end{array}$ & $\begin{array}{ll}\text { - } & \text { Room division expenditure } \\
\text { - } & \text { Energy costs and salaries } \\
\text { - } & \text { Non-salary expenses for property } \\
\text { - } & \text { Related expenses for variable advertising } \\
\text { - } & \text { Non-salary expenses for advertising } \\
\text { - } & \text { Fixed market expenditures } \\
\text { - } & \text { Payroll and related expenses for } \\
\text { administrative work } \\
\text { - } & \text { Non-salary expenses for administrative } \\
\text { work } & \end{array}$ & $\begin{array}{ll}\text { - } & \text { Total revenue } \\
\text { - } & \text { Level of service delivered } \\
\text { - } & \text { Market share and rate of } \\
\text { growth }\end{array}$ \\
\hline $\begin{array}{l}\text { Anderson et al. } \\
\text { (1999) }\end{array}$ & SFA & $\begin{array}{l}48 \text { U.S. hotels, } \\
1994\end{array}$ & $\begin{array}{ll} & \text { Number of employees } \\
\text { - } & \text { Number of rooms } \\
\text { - } & \text { Casino and entertainment Expenditures } \\
\text { - } & \text { Food expenditure } \\
\text { - } & \text { Other expenditure }\end{array}$ & $\begin{array}{l}\text { - Income from rooms } \\
\text { - Income from casino and } \\
\text { entertainment } \\
\text { Income from food and } \\
\text { others }\end{array}$ \\
\hline Tsaur (2001) & DEA & $\begin{array}{l}53 \text { Taiwan hotels, } \\
\text { 1996-1998 }\end{array}$ & $\begin{array}{l}\text { - Total operating expenses } \\
\text { - Number of employees } \\
\text { - Number of guest rooms } \\
\text { - Total floor space of the catering division } \\
\text { - Number of employees in the room division } \\
\text { - Number of employees in the catering } \\
\text { division } \\
\text { - Catering cost }\end{array}$ & $\begin{array}{l}\text { - Total operating revenues } \\
\text { - Number of rooms occupied } \\
\text { - Average daily rate } \\
\text { - Average production value } \\
\text { per employee in the catering } \\
\text { division } \\
\text { - Total operating revenues of } \\
\text { the room division } \\
\text { - Total operating revenues of } \\
\text { the catering division }\end{array}$ \\
\hline $\begin{array}{l}\text { Hwang \& } \\
\text { Chang (2003) }\end{array}$ & DEA & $\begin{array}{l}45 \text { Taiwan hotels } \\
\text { 1994-1998 }\end{array}$ & $\begin{array}{ll}\text { - } & \text { Number of full-time employees } \\
\text { - } & \text { Guest rooms } \\
\text { - } & \text { Total area of the meal department } \\
\text { a } & \text { Operating expenses }\end{array}$ & $\begin{array}{ll}\text { - } & \text { Room revenue } \\
\text { - } & \text { Food and beverage revenue } \\
\text { - } & \text { Other revenue }\end{array}$ \\
\hline $\begin{array}{l}\text { Chiang et al. } \\
\text { (2004) }\end{array}$ & DEA & $\begin{array}{l}25 \text { Taipei hotels } \\
2003\end{array}$ & $\begin{array}{ll}\text { - } & \text { Number of hotel rooms } \\
\text { - } & \text { Capacity of food and beverage } \\
\text { - } & \text { Number of employees } \\
\text { - Total costs of the hotel }\end{array}$ & $\begin{array}{l}\text { - Yielding index } \\
\text { - Revenue of food and } \\
\text { beverage } \\
\text { a } \quad \text { Miscellaneous revenue }\end{array}$ \\
\hline $\begin{array}{l}\text { Yang \& Lu } \\
(2006)\end{array}$ & DEA & $\begin{array}{l}56 \text { Taiwan hotels, } \\
2002\end{array}$ & $\begin{array}{ll}\text { - } & \text { Total operating expenses } \\
\text { - } & \text { Number of employees } \\
\text { - } & \text { Number of guest rooms } \\
\text { - } & \text { Total area of the catering division }\end{array}$ & $\begin{array}{l}\text { - Total operating revenue } \\
\text { - Average occupancy rate } \\
\text { - Average room rate } \\
\text { - Average production } \\
\text { - Value per employee in the } \\
\text { catering division } \\
\text { - Average production value } \\
\text { of the catering division }\end{array}$ \\
\hline Chen (2007) & SFA & $\begin{array}{l}55 \text { Taiwan hotels, } \\
2002\end{array}$ & $\begin{array}{ll}\text { - } & \text { Cost of labor } \\
\text { - } & \text { Total food and beverage expenses } \\
\text { - } & \text { Material costs } \\
\end{array}$ & - $\quad$ Total revenue \\
\hline Hu et al. (2009) & DEA & $\begin{array}{l}66 \text { Taiwan hotels, } \\
1997-2006\end{array}$ & $\begin{array}{ll}\text { - } & \text { Number of employees } \\
\text { - } & \text { Number of guest rooms } \\
\text { - } & \text { Total floor space of the catering division }\end{array}$ & $\begin{array}{ll}\text { - } & \text { Room revenue } \\
\text { - } & \text { Food and beverage revenue } \\
\text { - } & \text { Other revenue }\end{array}$ \\
\hline $\begin{array}{l}\text { Assaf et al. } \\
(2010)\end{array}$ & Meta-froniter & $\begin{array}{l}78 \text { Taiwan hotels } \\
\text { 2004-2008 }\end{array}$ & $\begin{array}{l}\text { Number of rooms } \\
\text { - Number of full-time equivalent employees } \\
\text { in the room division } \\
\text { Number of full-time equivalent employees } \\
\text { in the food and beverage division } \\
\text { Number of full-time equivalent employees } \\
\text { in other departments }\end{array}$ & $\begin{array}{l}\text { - Total room revenue } \\
\text { - Total food and beverage } \\
\text { revenue } \\
\text { - Total of other revenue } \\
\text { - Market share for each hotel } \\
\text { - Employees performance }\end{array}$ \\
\hline $\begin{array}{l}\text { Chen et al. } \\
\text { (2010) }\end{array}$ & DEA & $\begin{array}{l}66 \text { Taiwan hotels } \\
1996-2007\end{array}$ & $\begin{array}{ll}\text { - } & \text { Number of guest rooms } \\
\text { - } & \text { Number of employees } \\
\text { - } & \text { Total floor space of the catering division }\end{array}$ & $\begin{array}{l}\text { - Total revenue of food and } \\
\text { beverage } \\
\text { Total revenue of rooms } \\
\text { - Other revenue }\end{array}$ \\
\hline
\end{tabular}


The location of hotels in Taiwan has also been discussed many times (Yang \& Lu, 2006; Hung et al., 2006; Chen, 2007; $\mathrm{Hu}$ et al., 2009). These studies investigated which hotels located in which type of area (resort or metropolitan) would have significantly better efficiency, but the findings are inconsistent. Some of them noted no relationship between location and efficiency (Sun \& Lu, 2005; Chen, 2007), while some researchers found that a resort area had significantly positive impacts on efficiency (Yang \& Lu, 2006; Hu et al., 2009). Monty \& Skidmore (2003) stated that bed and breakfast accommodations located near tourist areas charge significantly higher than those located in other areas. Hung et al. (2010) said that due to the availability of more leisure amenities and scenic surroundings for resort hotels, hotels located near scenic areas appear to be more expensive. In the hotel industry, there is a lack of studies on the number of scenic spots around hotels. As mentioned before, more scenic spots around hotels mean that prices are much higher. Therefore, we are concerned about whether the more scenic spots surrounding a hotel result in higher efficiency scores for the hotel. This is a new idea in the hotel field.

This study has two purposes. One is to examine what products a hotel provides affect the selection of ITHs by different nationality tourists. The second purpose is to probe the influence of the number of scenic spots surrounding hotels on the cost efficiency of ITHs in Taiwan.

\section{Methodology and Data}

\subsection{Data Envelopment Analysis}

The definitions of efficiency scores were created by Farrell (1957). DEA, which is used to measure the efficiency of multiple decision-making units (DMUs), involves the use of linear programming methodology to construct a non-parametric piece-wise frontier over the data, and efficiency is calculated relative to the frontier. If a firm locates at the frontier line, then this firm is the most efficient one. On the contrary, if a firm locates outside of the frontier, then it is an inefficient firm. Farrell also divided cost efficiency (CE) into technical efficiency (TE) and allocative efficiency (AE):

$$
\text { Cost Efficiency }(C E)=\text { Technical Efficiency }(T E) \times \text { Allocative Efficiency (AE) }
$$

Charnes et al. (1978) proposed a model having an input orientation and constant returns to scale to compute the above efficiency. The input-orientated constant returns to scale model was the first to be widely applied.

This study assumes there are data on $\mathrm{K}$ inputs and $\mathrm{M}$ outputs for each of the $\mathrm{N}$ firms.

$$
\begin{gathered}
\operatorname{Min} w_{i}{ }^{\prime} x_{i}{ }^{*} \\
\text { s.t. }-q_{i}+Q \lambda \geq 0 \\
x_{i}{ }^{*}-X \lambda \geq 0 \\
\lambda \geq 0
\end{gathered}
$$

where $x_{i}$ represents the $\mathrm{K} \times 1$ input matrix, $q_{i}$ represents the $\mathrm{M} \times 1$ output matrix for the $i$-th firms, $Q$ is an $\mathrm{M} \times \mathrm{N}$ output matrix, $X$ is a $\mathrm{K} \times \mathrm{N}$ input matrix, and $\lambda$ is an $\mathrm{N} \times 1$ vector of constants. According to Farrell's definition, a firm with a value of 1 indicates the firm locates at the frontier and hence is a technically efficient firm, $w_{i}$ is a vector of input prices for the $i$-th firms, and $x_{i}^{*}$ is the cost-minimizing vector of input quantities for the $i$-th firms, given the input prices $w_{i}$, and the output levels $q_{i}$. Moreover, CE is defined as the ratio of minimum cost to observed cost. Therefore, $\mathrm{CE}$ is described as follows:

$$
C E=w_{i}^{\prime} x_{i}^{*} / w_{i}^{\prime} x_{i}
$$

The allocative efficiency is presented as:

$$
A E=C E / T E
$$

These three indicators range from 0 to 1 . A value of $\mathrm{CE}$, TE, and $\mathrm{AE}$ equal to 1 represents full efficiency.

\subsection{Tobit Regression}

The Tobit analysis was derived from Tobin in 1958. The Tobit approach is used to explore what external operational environments affect the relative efficiency scores across production firms. According to Fried et al. (1999), characteristics of the external environment could influence the ability of management to transform inputs into outputs. Therefore, the Tobit regression analysis estimates the relationship between efficiency scores and operating characteristics of the external environment in international tourist hotels. Tobin (1958) further showed that the Tobit regression is better than Ordinary Least Squares (OLS) in censored data, because the former is more effective and consistent. Since the efficiency scores are censored at 0 and 1 , the Tobit regression is more appropriate for estimation. Therefore, the Tobit regression investigates whether these environment variables 
(number of tourists by nationality, number of scenic spots, number of basic services, rate of individual tourists, type of operation, distance to nearest international airport, number of restaurants, and year founded) affect the inefficiency scores.

\subsection{Panel Data}

We collected cross-section and time-series data. If we use the traditional approach OLS to analyze this data, then we get a bias estimation, because the OLS assumes all samples have the same intercept. Therefore, we adopt the panel data regression, which is a special type of pooled cross-section/time-series data, and each firm is sampled over time in panel data.

Panel data usually contain more degrees of freedom and less multicollinearity than cross-sectional data or time series data, hence improving the efficiency of econometric estimates (Hsiao 2006). The standard regression model of panel data takes the form of:

$$
R_{i t}=\alpha_{i}+\sum_{i=1}^{K} \beta_{k} Z_{k i t}+\varepsilon_{i t}
$$

where $i$ represents the $i$-th firm, $i=1,2, \ldots, \mathrm{N} ; t$ represents the period $t=1,2, \ldots, \mathrm{T} ; R_{i t}$ is the dependent value of the $i$-th firm in period $t ; \alpha_{i}$ represents the intercept of the $i$-th firms; $\beta_{k}$ is the regression coefficient of the $k$-th explanatory variable; $Z_{k i t}$ presents the explanatory variable value of the $k$-th firm in period $t$; and $\varepsilon_{i t}$ is the error component.

We notice that the panel data model allows the different samples to have different intercepts. According to the different assumptions of intercept, there are two types of model: the fixed-effects model and the random-effects model. In general, the fixed-effects model just infers the individual data we have. Moreover, the random-effect model regards the data we collect as a random sample of the population.

This study uses unbalanced panel data from the period 1997 to 2007. We collect all the data from the annual Operating Report of International Tourist Hotels in Taiwan published by the TTB and the websites of hotels. The numbers of ITHs vary every year, because the TTB re-checks ITHs in Taiwan. If the hotel is unqualified or the hotel has closed down, then it will be removed from the annual Operating Report of International Tourist Hotels. The numbers of observations from 1998 to 2007 are as follows: 1998 (52 hotels), 1999 (54), 2000 (54), 2001 (54), 2002 (55), 2003 (57), 2004 (57), 2005 (56), 2006 (57), and 2007 (56), making 652 observations in total.

\subsubsection{Output Variables}

- Total revenues from food and beverages $\left(y_{1}\right)$ : the revenue from sales of food, snacks, alcohol, and beverages in catering (tips not included); measured in units of NT\$.

NT\$.

- Other revenues $\left(y_{3}\right)$ : incomes excluding revenues from food \& beverages and rooms. They include operating revenues from the leasing of store space, laundry, swimming pool, ball courts, barber shop, beauty salons, and bookstores; measured in units of NT\$.

\subsubsection{Input Variables}

- Number of guest rooms rented per year $\left(x_{1}\right)$ : the amount of guest rooms that can be rented from an international tourist hotel, representing the scale of the hotel.

- Number of employees $\left(x_{2}\right)$ : total employees involved in the operation of international tourist hotels.

- Total floor space of the catering division $\left(x_{3}\right)$ : the total floor space used by the operational units of all hotels' catering facilities; measured in square feet.

3.3.3 Input Prices

- Average price of room operations $\left(w_{1}\right)$ : total operating expenses per room; measured in NT\$/room.

- Average employee's annual wage $\left(w_{2}\right)$ : salary and related expenses per employee; measured in NT\$/individual.

- Average price of $\mathrm{F} \& \mathrm{~B}$ operations $\left(w_{3}\right)$ : the catering department expenses per square meter of floor space; measured in NT\$/square meter.

\subsubsection{Environmental Variables}

- Number of tourists by nationality: the number of local Taiwanese, overseas Chinese, North American, Japanese, Asian, European, and Australian tourists in each hotel. 
- Distance to the airport: the distance between the hotel and the nearest Taiwan international airport.

- Type of operation: we use a dummy variable to distinguish two types of hotel operation. ' 0 ' represents independent operation; ' 1 ' represents hotels joining a chain operation.

- Number of scenic spots: the number of scenic spots located in the hotel's surroundings within a 15-minute ride. The scenic spots are defined by TTB, which include national scenic areas, national parks, government sites, county scenic areas, forest recreation areas, beach, amusement/theme sites, historic sites and others.

A summary of statistics for these outputs, inputs, and input prices are listed in Table 2. Note that the mean total revenue of food and beverage is higher than the mean total revenue from rooms, reflecting the special phenomenon in Taiwan that local people usually go to ITHs for food and beverage services (such as wedding ceremonies, birthday banquets, classmate reunions, family get-togethers, business talks, etc.) rather than staying in the guestrooms.

Table 2. Descriptive statistics of outputs, inputs, and input prices (Unit $=$ NT dollars)

\begin{tabular}{|c|c|c|c|c|}
\hline Variable & Mean & $\mathrm{SD}$ & Minimum & Maximum \\
\hline Total revenues from food and beverages $\left(y_{1}\right)$ & $268,211,000$ & $264,538,842.9$ & 0 & $1,284,793,160$ \\
\hline Total revenues from rooms $\left(y_{2}\right)$ & $223,024,871.2$ & $206,866,345.3$ & $7,044,733$ & $1,389,697,939$ \\
\hline Other revenue $\left(y_{3}\right)$ & $92,455,471$ & $5,370,918$ & 0 & $702,395,789.4$ \\
\hline Number of guest rooms $\left(x_{1}\right)$ & $72,252.5$ & $1,884.784$ & 3,910 & 246,626 \\
\hline Number of employees $\left(x_{2}\right)$ & 334.2 & 235 & 25 & 1,230 \\
\hline Total floor space of the catering division $\left(x_{3}\right)$ & $1,137.4$ & $1,128.4$ & 0 & 12,037 \\
\hline Average price of room operations $\left(w_{1}\right)$ & $2,874.5$ & $1,233.8$ & 833.2 & $8,907.7$ \\
\hline Average employee annual wage $\left(w_{2}\right)$ & $493,650.9$ & $146,798.2$ & $82,714.9$ & $903,692.3$ \\
\hline Average price of $\mathrm{F} \& \mathrm{~B}$ operations $\left(w_{3}\right)$ & $100,772.3$ & $100,066.6$ & 0 & 188,7736 \\
\hline
\end{tabular}

\section{Empirical Result and Discussion}

\subsection{Operational Efficiency Analysis}

The efficiency of a firm usually means success in producing the largest output from a given set of inputs. This study employs DEA to estimate the operational efficiency of ITHs in Taiwan and to compute the efficiency scores of each hotel from 1998 to 2007 . Because the model's adoption is input-orientated, we compute the slack of input variables (number of guest rooms rented per year, number of employees, and total floor space of catering division). The average cost efficiency score is 0.622 and indicates hotels could reduce their input costs by $37.8 \%$ without decreasing any output. The maximum hotel efficiency score is 1 , while the minimum efficiency score is 0.3264 .

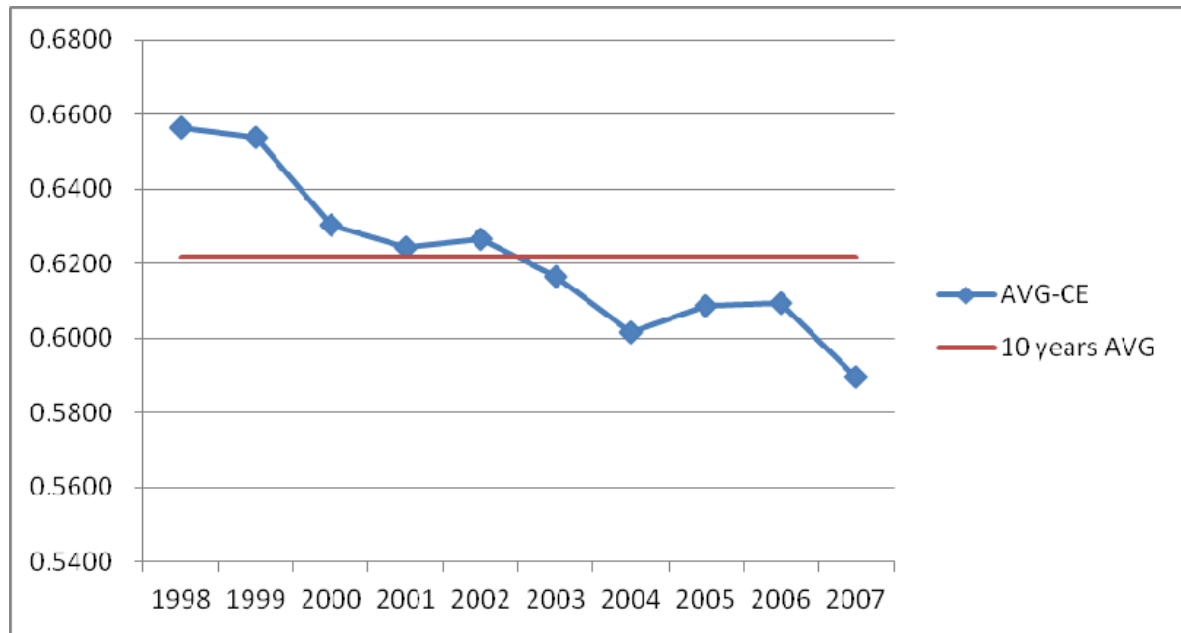

Figure 1. The trend of international tourist hotels' cost efficiency scores in Taiwan 
Figure 1 is the trend chart of the average value of each year from 1998 to 2007 and shows that average cost efficiency decreased gradually. Two apparent recessions of cost efficiency are from 1999 to 2000 and from 2002 to 2004. The first recessions (1999-2000) of cost efficiency is due to Taiwan's 921 Earthquake registering 7.3 on the Richter scale in September 1999. The earthquake caused 2,415 deaths, 29 missing people, 11,305 injured and 51,711 houses completely destroyed, and the total economic losses were up to USD 11.25 billion. Foreign visitors in the fourth quarter of 1999 were $18.5 \%$ less than the same period of the previous year. We find that Japanese visitors were the most affected and the ratio of Japanese visitors dropped from $36.6 \%$ to $29.9 \%$. In addition, TTB estimated the earthquake resulted in a reduction of approximately USD 205 million in tourism foreign exchange earnings. Therefore, the dramatic decline of cost efficiency and allocative efficiency reflected the impact of the seriousness of this disaster.

The total guestrooms' supply increased 9,357 rooms and the average price of guestrooms decreased by about USD 6.6 from 2002 to 2004. In 2003, the SARS epidemic in Asia caused the total number of visitor arrivals to decline severely by $24.5 \%$ and cost efficiency also dropped. Based on the above information, we can understand that the operational efficiency of Taiwan's hotel industry fluctuated with the economic environment or critical events.

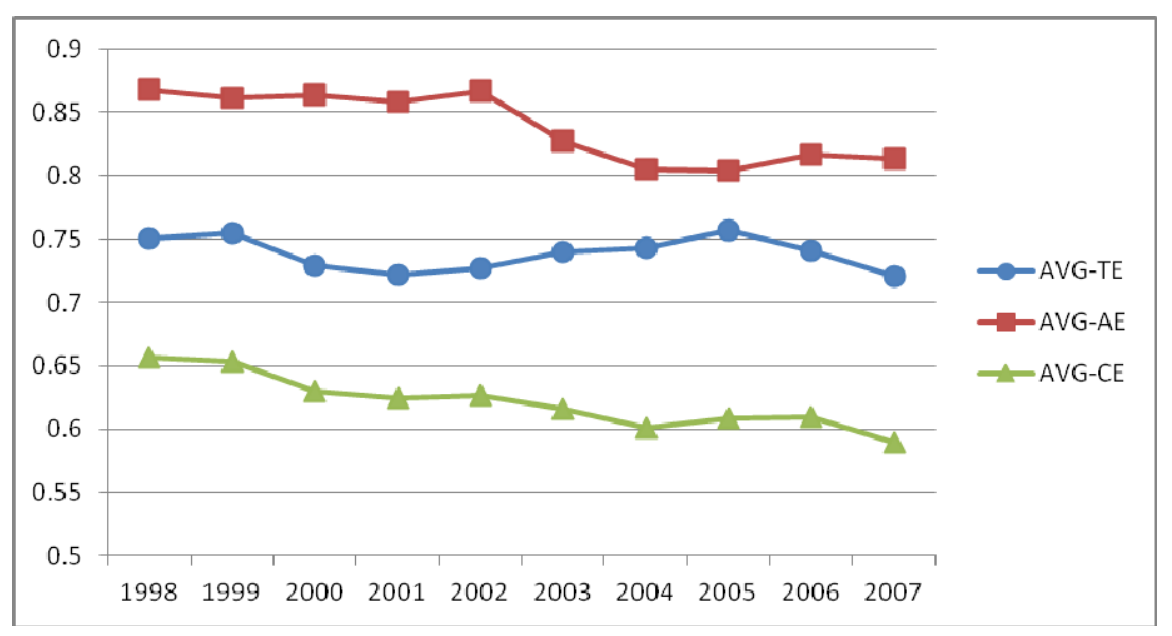

Figure 2. The trend of international tourist hotels' cost, technical, and allocative efficiency scores in Taiwan

As Figure 2 shows, the directions of cost efficiency and allocative efficiency are almost consistent, and the effect of allocative efficiency dominates that of cost efficiency. Hu et al. (2009) also found that the cost efficiency in Taiwan follows the trend of allocative efficiency, illustrating that ITHs in Taiwan are facing fierce competition. The total number of international hotels' guestrooms in Taiwan increased from 160,330 in 1990 to 233,378 in 2010 and the growth rate was about $45.56 \%$ during these ten years. Therefore, how to distribute resources efficiently is an important issue for ITHs in Taiwan. As a result, we analyze which nationality has the most positive relationship with efficiency and then investigate the relationship between services/facilities and different nationality tourists.

\subsection{Results of Tobit Regression}

We use the Tobit censored regression model to assess the influence of various management or environmental factors on the efficiency scores of ITHs. There are several environmental variables selected in this study: type of operation (Type; 1 = chain, 0 = independent), distance to the nearest international airport (Distance), the ratio of individual tourists (Individual), number of scenic spots (Scenic), number of tourists by nationality, number of services provided by hotel (Service), and time of establishment (Years). The cost efficiency scores are used as dependent variables in each Tobit regression equation. Table 3 lists the Tobit regression results on cost efficiency and shows that the number of local Taiwanese, North American, and Japanese tourists will increase the cost efficiency of ITHs in Taiwan. The number of overseas Chinese will decrease cost efficiency, while Australian tourists and European tourists have no effect on cost efficiency. The chain-operated type of hotel significantly increases ITHs' cost efficiency, and this result is consistent with most past studies. 
Table 3. Tobit regression results: $\mathrm{CE}$ as the dependent variable

\begin{tabular}{lllll}
\hline Variable & Coefficient & Std. Error & t-value & P-value \\
\hline Constant & 0.3787 & 0.051653 & 7.331799 & $<0.0001^{* * *}$ \\
Overseas Chinese & -1.809 & 9.3707 & -1.975337 & $0.0482^{* *}$ \\
Asian & 1.110 & 6.287 & 1.769970 & $0.0767^{*}$ \\
Australian & -6.1667 & 1.035 & -0.600494 & 0.5482 \\
European & -3.406 & 2.766 & -1.250878 & 0.2110 \\
Japanese & 8.537 & 3.757 & 2.273235 & $0.0230^{* *}$ \\
North American & 8.4801 & 1.356 & 6.264049 & $<0.001^{* * *}$ \\
Local & 6.1101 & 1.627 & 3.781641 & $<0.001^{* * *}$ \\
Individual & 0.1632 & 0.038066 & 4.286145 & $<0.001^{* * *}$ \\
Distance & 0.0058 & 0.018196 & 0.320036 & 0.7489 \\
Scenic & 0.0082 & 0.002458 & 3.315794 & $<0.001^{* * *}$ \\
Spring & 0.1785 & 0.027967 & 6.382463 & $<0.001^{* * *}$ \\
Type & 0.0812 & 0.015208 & 5.345024 & $<0.001^{* * *}$ \\
Service & -0.0188 & 0.008703 & -2.158985 & $0.0309^{* * *}$ \\
\hline
\end{tabular}

Note. $* * *, * *$, and $*$ represent significance at the $1 \%, 5 \%$, and $10 \%$ levels.

The number of scenic spots surrounding the hotel has significantly positive effects on cost efficiency. The more scenic spots there are that surround hotels, the higher their cost efficiency will be. A hotel that provides a hot spring facility also displays a significantly positive influence on cost efficiency. According to the TTB's survey, the factors to attract international and domestic tourists are natural scenery and local cuisines in Taiwan. Therefore, scenic spots are important considerations for tourists to make their selection from different hotel choices. Furthermore, the finding points out that the number of services provided by a hotel has significantly negative lower cost efficiency, and a hotel that just only provides the basic services cannot attract tourists, but more services will lead to higher cost and more inefficiency.

Taking another dummy variable into consideration, we find that accommodation of more individual tourists has a significantly positive influence on cost efficiency. The study finds that the price per guestroom has a significantly positive relationship with the ratio of individual tourists, and a hotel accommodating more individual tourists shows a significantly positive influence on cost efficiency. In other words, the more individual tourists the hotel accommodates, the higher price an average guestroom will be. Therefore, the hotel can use the same cost to get more revenue and improve cost efficiency.

\subsection{Analysis of Tourists' Preferences}

This paper uses the annual number of arrivals to ITHs in Taiwan as the measurement for the volume of different nationality tourists over the period 1998 to 2007. The independent variables include number of rooms (representing the scale of a hotel; Scale), number of scenic spots (Scenic), time of establishment (Years), the distance between the hotel and nearest international airport (Distance), the type of operation (Operation), and the services (Gym, Meeting Room, Shuttle, and Swimming Pool). The numbers of different nationality tourists are used as variables in each regression equation.

Table 4 indicates that a hotel's time of establishment shows a significantly positive influence on the number of tourists - that is, a more early development time of hotels could attract more tourists. The number of rooms also displays a significantly positive influence on the number of tourists and implies tourists prefer larger-scale ITHs. For all tourists, the distance between the hotel and the nearest international airport has a positive relationship. To sum up, hotels that are larger, older, and closer to the nearest international airport have the advantage to attract more tourists. 
Table 4. Panel data results

\begin{tabular}{|c|c|c|c|c|c|c|c|}
\hline Variable & $\begin{array}{l}\text { Overseas } \\
\text { Chinese }\end{array}$ & Asian & European & Local & Japanese & $\begin{array}{l}\text { North } \\
\text { American }\end{array}$ & Australian \\
\hline Constant & $\begin{array}{l}1.09052 \\
(0.2760)\end{array}$ & $\begin{array}{l}-0.62421 \\
(0.5328)\end{array}$ & $\begin{array}{l}-0.69148 \\
(0.4896)\end{array}$ & $\begin{array}{l}0.36278 \\
(0.7169)\end{array}$ & $\begin{array}{l}-0.65155 \\
(0.5150)\end{array}$ & $\begin{array}{l}-0.91870 \\
(0.3587)\end{array}$ & $\begin{array}{l}1.35663 \\
(0.1755)\end{array}$ \\
\hline Scale & $\begin{array}{l}0.411064 \\
(0.6812)\end{array}$ & $\begin{array}{l}7.74071 \\
(<0.01 * * *)\end{array}$ & $\begin{array}{l}5.816163 \\
(<0.01 * * *)\end{array}$ & $\begin{array}{l}1.961636 \\
(0.0503 * *)\end{array}$ & $\begin{array}{l}4.26918 \\
(<0.01 * * *)\end{array}$ & $\begin{array}{l}5.53836 \\
(<0.01 * * *)\end{array}$ & $\begin{array}{l}1.875424 \\
\left(0.0613^{*}\right)\end{array}$ \\
\hline Scenic & $\begin{array}{l}-0.626486 \\
(0.5313)\end{array}$ & $\begin{array}{l}-1.03837 \\
(0.2996)\end{array}$ & $\begin{array}{l}0.412757 \\
(0.6800)\end{array}$ & $\begin{array}{l}-2.03294 \\
\left(0.0426^{* *}\right)\end{array}$ & $\begin{array}{l}3.567888 \\
(<0.01 * * *)\end{array}$ & $\begin{array}{l}-0.79961 \\
(0.4243)\end{array}$ & $\begin{array}{l}1.35472 \\
(0.1761)\end{array}$ \\
\hline Years & $\begin{array}{l}2.616695 \\
(<0.01 * * *)\end{array}$ & $\begin{array}{l}3.06906 \\
(<0.01 * * *)\end{array}$ & $\begin{array}{l}-1.05711 \\
(0.2910)\end{array}$ & $\begin{array}{l}2.61106 \\
(<0.01 * * *)\end{array}$ & $\begin{array}{l}1.87050 \\
\left(0.0620^{*}\right)\end{array}$ & $\begin{array}{l}1.48704 \\
(0.1376)\end{array}$ & $\begin{array}{l}-3.40308 \\
(<0.01 * * *)\end{array}$ \\
\hline Distance & $\begin{array}{l}-0.543251 \\
(0.5872)\end{array}$ & $\begin{array}{l}-1.01429 \\
(0.3109)\end{array}$ & $\begin{array}{l}-1.53054 \\
(0.1265)\end{array}$ & $\begin{array}{l}2.32857 \\
(0.0203 * *)\end{array}$ & $\begin{array}{l}0.53231 \\
(0.5947)\end{array}$ & $\begin{array}{l}-0.66159 \\
(0.5085)\end{array}$ & $\begin{array}{l}-1.50579 \\
(0.1327)\end{array}$ \\
\hline Spring & $\begin{array}{l}0.031996 \\
(0.9745)\end{array}$ & $\begin{array}{l}0.81276 \\
(0.4167)\end{array}$ & $\begin{array}{l}-1.34678 \\
(0.1786)\end{array}$ & $\begin{array}{l}0.05660 \\
(0.9549)\end{array}$ & $\begin{array}{l}0.66561 \\
(0.5060)\end{array}$ & $\begin{array}{l}-1.27512 \\
(0.2028)\end{array}$ & $\begin{array}{l}-1.24917 \\
(0.2122)\end{array}$ \\
\hline Type & $\begin{array}{l}-0.930427 \\
(0.3526)\end{array}$ & $\begin{array}{l}-0.64281 \\
(0.5206)\end{array}$ & $\begin{array}{l}1.01189 \\
(0.3121)\end{array}$ & $\begin{array}{l}-0.35577 \\
(0.7222)\end{array}$ & $\begin{array}{l}1.29312 \\
(0.1965)\end{array}$ & $\begin{array}{l}2.653538 \\
(<0.01 * * *)\end{array}$ & $\begin{array}{l}-0.52247 \\
(0.6016)\end{array}$ \\
\hline Gym & $\begin{array}{l}0.520087 \\
(0.6032)\end{array}$ & $\begin{array}{l}0.82139 \\
(0.4118)\end{array}$ & $\begin{array}{l}0.71029 \\
(0.4778)\end{array}$ & $\begin{array}{l}-1.77561 \\
(0.8862)\end{array}$ & $\begin{array}{l}-0.38427 \\
(0.7009)\end{array}$ & $\begin{array}{l}0.710220 \\
(0.4779)\end{array}$ & $\begin{array}{l}1.12035 \\
(0.2631)\end{array}$ \\
\hline Meeting & $\begin{array}{l}-0.495609 \\
(0.6204)\end{array}$ & $\begin{array}{l}-0.66308 \\
(0.5076)\end{array}$ & $\begin{array}{l}0.24425 \\
(0.8071)\end{array}$ & $\begin{array}{l}0.42203 \\
(0.6732)\end{array}$ & $\begin{array}{l}-1.26233 \\
(0.2074)\end{array}$ & $\begin{array}{l}0.162237 \\
(0.8712)\end{array}$ & $\begin{array}{l}0.33001 \\
(0.7415)\end{array}$ \\
\hline Shuttle & $\begin{array}{l}-0.441977 \\
(0.6587)\end{array}$ & $\begin{array}{l}0.19882 \\
(0.8425)\end{array}$ & $\begin{array}{l}1.11869 \\
(0.2638)\end{array}$ & $\begin{array}{l}-0.01092 \\
(0.9913)\end{array}$ & $\begin{array}{l}0.926837 \\
(0.3544)\end{array}$ & $\begin{array}{l}0.559292 \\
(0.5762)\end{array}$ & $\begin{array}{l}0.95217 \\
(0.3414)\end{array}$ \\
\hline $\begin{array}{l}\text { Swimming } \\
\text { Pool }\end{array}$ & $\begin{array}{l}0.372082 \\
(0.7100)\end{array}$ & $\begin{array}{l}-1.18663 \\
(0.2359) \\
\end{array}$ & $\begin{array}{l}-0.82332 \\
(0.4107)\end{array}$ & $\begin{array}{l}0.96014 \\
(0.3374)\end{array}$ & $\begin{array}{l}-0.60528 \\
(0.5453)\end{array}$ & $\begin{array}{l}-1.02984 \\
(0.3036)\end{array}$ & $\begin{array}{l}2.129047 \\
(<0.01 * * *)\end{array}$ \\
\hline $\mathrm{R}^{2}$ & 0.2061 & 0.453 & 0.463 & 0.174 & 0.474 & 0.393 & 0.476 \\
\hline
\end{tabular}

Note. Numbers in parentheses are the p-values. Notations $* * *, * *$, and * represent significance at the $1 \%, 5 \%$, and $10 \%$ levels.

In order to enhance operational efficiency, this study looks at what nationality has significantly positive effects on cost efficiency and further investigates the effects of these factors on each nationality tourists. The finding reveals that Asian, Japanese, local Taiwanese and North American tourists can significantly improve cost efficiency. Asian tourists, including those from mainland China, have a positive relationship with time of establishment and the scale of the hotel, indicating that earlier established hotels could attracts more Asian tourists. The study indicates the local tourists also show a significantly positive relationship with time of establishment, the distance to the nearest international airport, and the scale of the hotel. Additionally, the finding points out that local tourists have a negative relationship with the number of scenic spots, however, it does not represent they do not like a hotel surrounded by special scenery. According to the TTB's statistics, about $47.1 \%$ of local tourists' most favorite activity is visiting the natural landscape. In Taiwan, even if one stays at hotels located in a metropolitan area, most scenic spots are located within 15 minutes distance of driving. The island's convenient transportation system allows domestic tourists to easily reach the scenic spots. That is why there is a negative relationship between the number of local tourists and the number of scenic spots.

Both the scale of a hotel and the number of scenic spots have significantly positive influences on Japanese tourists, especially as larger-scale hotels and more scenic spots surrounding hotels can attract more Japanese tourists. The study finds that North American tourists have a positive relationship with the scale of the hotel and the type of operation, and they prefer larger-scale and chain-operated hotels.

\section{Conclusion}

Because ITHs in Taiwan are facing growing competition, especially after the latest global financial crisis happened, how to manage ITHs efficiently is an important key issue for managers. The DEA technique is frequently used to estimate efficiency in terms of the frontier concept. Therefore, this study adopts the DEA model, including three input variables, three output variables, and three input prices, to compute cost, technical, and allocative efficiencies and to explore the cross period efficiency of ITHs in Taiwan during the period 1998 to 2007. The result reveals ITHs in Taiwan on average have an operating efficiency at 0.622 , implying that managers could reduce input costs by $37.8 \%$. 
This study further employs the Tobit regression to examine environmental variables' effect on hotels' efficiency and notes some findings. First, the cost efficiency of a hotel that accommodates more local, North American, Asian, and Japanese tourists is higher than others. Regarding Australian tourists and European tourists, they have no relationship with both technical and allocative efficiencies. Second, the cost efficiency of a chain hotel is higher than that of an independent hotel. Third, the more scenic spots or hot springs that surround hotels, the higher cost efficiency the hotels will have. Finally, the higher individual tourist ratio a hotel has, the higher its cost efficiency will be.

This study also investigates the preferences of different nationality tourists. Local tourists prefer larger and older hotels and want to stay away from a city. Japanese tourists prefer larger hotels with more scenic spots surrounding them. According to the TTB Yearbook (2010), Japanese tourists accounted for over $30 \%$ of all inbound tourists, and their average expenditure was USD 314.22 per person per day, including USD 125.54 spent inside the hotel, which are both higher than tourists from other regions. Therefore, larger hotels that more scenic spots surrounded can attract Japanese tourists and can make hotels operate efficiently. Asian tourists, including mainland China, and North American tourists are both the main inbound tourists to Taiwan. The former prefers larger and older hotels and the latter prefers larger and chain-operated hotels. Most inbound tourists come from mainland China. Their average expenditure was USD 234.26 per person per day, the second highest among inbound tourists, and they totaled about 1,630,735 person-times in 2010.

After Taiwan opened its doors to mainland Chinese in July 2008, nearly 2.3 million of them had visited Taiwan as of May 31, 2011, spending a total of USD 4.14 billion. After the agreement on the individual travel program for mainland Chinese tourists was inked by the Taipei-based Straits Exchange Foundation (SEF) and its Beijing counterpart, the Association for Relations across the Taiwan Straits (ARATS), it officially took effect on June 28 , 2011. The Mainland Affairs Council (MAC) in Taiwan cited this as a milestone in boosting stronger cross-strait ties after Taiwan first opened its doors to group visits by mainland Chinese tourists in mid-2008. The new deal will foster the grassroots economy, because mainland Chinese tourists tend to shop much more than tourists from Western countries. TTB statistics show that mainland Chinese visitors spend $80 \%$ of their travel expenditure on shopping and $20 \%$ on accommodations, while Western visitors are the opposite, choosing to splurge on hotels and shop less. As the daily limit on the number of independent mainland Chinese tourists is set at 500 people, an estimated USD 315 to 675 million in income from foreign exchange is expected every year. Mainland Chinese tourists were banned from partaking in most activities in Taiwan in the past times, but the Taiwan government nowadays is willing to supply such services according to their needs. As such, the hotel industry should roll out packages that promote and grasp this new opportunity.

The study also finds significantly positive effects on cost efficiency by increasing local, North America, Japanese, and Asian tourists. ITHs' managers in Taiwan should regard these tourists as targeted customers to enhance their cost efficiency. Additionally, a hotel should increase the ratio of individual tourists, because a higher ratio can enhance its cost efficiency. This study also shows that tourists from different nations do have different preferences over ITHs. Therefore, based on the findings of this study, hoteliers should re-think their targeted customers' demands and re-design management strategies in order to enhance cost efficiency and to attract specific groups of tourists.

\section{Aknowledgements}

The authors thank two anonymous referees of this journal for their valuable comments. Financial support from Taiwan's Ministry of Science and Technology (NSC100-2410-H-009-051) is gratefully acknowledged.

\section{References}

Aigner, A., Lovell, C. A. K., \& Schmidt, P. (1977). Formulation and estimation of stochastic frontier production function models. Journal of Econometrics, 86, 21-37. http://dx.doi.org/10.1016/0304-4076(77)90052-5

Anderson, R. I., Fish, M., Xia, Y., \& Mixhello, F. (1999). Measuring efficiency in the hotel industry: A stochastic approach. International Journal of Hospitality Management, 18, 45-57. http://dx.doi.org/10.1016/S0278-4319(98)00046-2

Assaf, A., Barros, C. P., \& Josiassen, A. (2009). Hotel efficiency: A bootstrapped metafrontier approach. International Journal of Hospitality Management, 29(3), 468-475. http://dx.doi.org/10.1016/j.ijhm.2009.10.020

Banker, R. D., Charnes, A., \& Cooper, W. W. (1984). Some models for estimating technical and scale inefficiencies in data envelopment analysis. Management Science, 30, 1078-1092. 
Barros, C. P. (2005). Measuring Efficiency in the Hotel Sector. Annals of Tourism Research, 32(2), 456-477. http://dx.doi.org/10.1016/j.annals.2004.07.011

Cai, L. A., Feng, R., \& Breiter, D. (2004). Tourist purchase decision involvement and information preferences. Journal of Vacation Marketing, 10(2), 138-148. http://dx.doi.org/10.1177/135676670401000204

Chan, E. S. W., \& Wong, S. C. K. (2006). Hotel selection: When price is not the issue. Journal of Vacation Marketing, 12(2), 142-159. http://dx.doi.org/10.1177/1356766706062154

Charnes, A. W., Cooper, W. W., \& Rhodes, E. (1978). Measuring the efficiency of decision making units. European Journal of Operational Research, 3, 429-444. http://dx.doi.org/10.1016/0377-2217(78)90138-8

Chen, C. F. (2007). Applying the stochastic frontier approach to measure hotel managerial efficiency in Taiwan. Tourism Management, 28(3), 696-702. http://dx.doi.org/10.1016/j.tourman.2006.04.023

Chen, C. M., Yeh, C. Y., \& Hu, J. L. (2011). The Influence of Uncertain Demand on Product Variety: Evidence from the International Tourist Hotel Industry in Taiwan. Tourism Economics, 17(6), 1275-1285. http://dx.doi.org/10.5367/te.2011.0089

Chen, C. T., Hu, J. L., \& Liao, J. J. (2010). Tourist Nationality Sources and Cost Efficiency of International Tourist Hotels in Taiwan. African Journal of Business Management, 4(16), 3440-3446.

Chiang, W., Tsai, M., \& Wang, L. S. (2004). A DEA evaluation of Taipei hotels. Annals of Tourism Research, 31, 712-715. http://dx.doi.org/10.1016/j.annals.2003.11.001

Coelli, T. (1996). A Guide to FRONTIER Version 4.1: A Computer Program for Stochastic Frontier Production and Cost Function Estimation. CEPA Working Paper 96/7, Department of Econometrics, University of New England, Armidale, Australia.

Farrell, M. J. (1957). The measurement of productive efficiency. Journal of the Royal Statistical Society, Part A, 120(3), 253-290. http://dx.doi.org/10.2307/2343100

Fried, H. O., Schmidt, S. S., \& Yaisawarng, S. (1999). Incorporating the operating environment into a nonparametric measure of technical efficiency. Journal of Productivity Analysis, 12, 249-267. http://dx.doi.org/10.1023/A:1007800306752

Hsiao, C. (2003). Analysis of Panel Data. Cambridge, UK: Cambridge University Press.

Hsieh, L. F., \& Lin, L. H. (2010). A performance evaluation model for international tourist hotels in Taiwan -an application of the relational network DEA. International Journal of Hospitality Management, 29(1), 14-24. http://dx.doi.org/10.1016/j.ijhm.2009.04.004

Hsu, T. K., Tsai, Y. F., \& Wu, H. H. (2009). The preference analysis for tourist choice of destination: A case study of Taiwan. Tourism Management, 30(2), 288-297. http://dx.doi.org/10.1016/j.tourman.2008.07.011

Hu, J. L., Chiu, C. N., Shieh, H. S., \& Huang, C. H. (2010). A stochastic cost efficiency analysis of international tourist hotels in Taiwan. International Journal of Hospitality Management, 29(1), 99-107. http://dx.doi.org/10.1016/j.ijhm.2009.06.005

Hu, J. L., Shieh, H. S., \& Ding, J. F. (2013). Self-Positioning of International Tourist Hotels in Taiwan. International Journal of Business and Management, 8(17), 71-83. http://dx.doi.org/10.5539/ijbm.v8n17p71

Hu, J. L., Shieh, H. S., Huang, C. H., \& Chiu, C. N. (2009). Cost efficiency of international tourist hotels in Taiwan: A data envelopment analysis application. Asia Pacific Journal of Tourism Research, 14(4), 371-384. http://dx.doi.org/10.1080/10941660903310060

Hwang, S. N., \& Chang, T. Y. (2003). Using data envelopment analysis to measure hotel managerial efficiency $\begin{array}{llll}\text { change in } \quad \text { Taiwan. } & \text { Tourism }\end{array}$ http://dx.doi.org/10.1016/S0261-5177(02)00112-7

Lehto, X. Y., Cai, L. A., O’Leary, J. T., \& Huan, T. C. (2004). Tourist shopping preferences and expenditure behaviors: The case of the Taiwanese outbound market. Journal of Vacation Marketing, 10(4), 320-332. http://dx.doi.org/10.1177/135676670401000404

Lew, A. A. (1987). A framework of tourist attraction research. Annals of Tourism Research, 14(4), 553-575. http://dx.doi.org/10.1016/0160-7383(87)90071-5

Meeusen, W., \& van Den Broeck, J. (1977). Efficiency estimation from Cobb-Douglas production functions with composed error. International Economic Review, 18, 435-444. http://dx.doi.org/10.2307/2525757 
Monty, B., \& Skidmore, M. (2003). Hedonic pricing and willingness to pay for bed and breakfast amenities in southeast Wisconsin. Journal of Travel Research, 42(2), 195-199. http://dx.doi.org/10.1177/0047287503257500

Morey, R., \& Dittman, D. (1995). Evaluating a hotel GM's performance: a case study in benchmarking. Cornell Hotel Restaurant and Administration Quarterly, 36(5), 30-35. http://dx.doi.org/10.1177/001088040304400507

Pizam, A., \& Sussmann, S. (1995). Does nationality affect tourist behavior? Annals of Tourism Research, 22(4), 901-917. http://dx.doi.org/10.1016/0160-7383(95)00023-5

Saleh, F., \& Ryan, C. (1992). Client perceptions of hotels: A multi-attribute approach. Tourism Management, 13(2), 163-168. http://dx.doi.org/10.1016/0261-5177(92)90058-F

Shieh, H. S. (2012). The greener, the more cost efficient? An empirical study of international tourist hotels in Taiwan. International Journal of Sustainable Development \& World Ecology, 19(6), 536-545. http://dx.doi.org/10.1080/13504509.2012.741627

Sun, S., \& Lu, W. M. (2005). Evaluating the performance of the Taiwanese hotel industry using a weight slacks-based measure. Asia-Pacific Journal of Operational Research, 22(4), 487-512. http://dx.doi.org/10.1142/S0217595905000595

Tarasewich, P. (1996). Design for success. Industrial Management, 38, 28-31. http://dx.doi.org/10.1243/0954410981532342

Tobin, J. (1958). Estimation of Relationships for Limited Dependent Variables. Econometrica, 26, 24-36. http://dx.doi.org/10.2307/1907382

Tourism Bureau of Taiwan. (2010). Retrieved from http://admin.taiwan.net.tw

Tran, X., \& Ralston, L. (2006). Tourist preferences influence of unconscious needs. Annals of Tourism Research, 33(2), 424-441. http://dx.doi.org/10.1016/j.annals.2005.10.014

Tsaur, S. H. (2001). The operating efficiency of international tourist hotels in Taiwan. Asia Pacific Journal of Tourism Research, 6(1), 73-81. http://dx.doi.org/10.1080/10941660108722090

Wang, F. C., Hung, W. T., \& Shang, J. K. (2006). Measuring the cost efficiency of international tourist hotels in $\begin{array}{llll}\text { Taiwan. } \quad \text { Tourism } & \text { Economics, }\end{array}$ http://dx.doi.org/http://dx.doi.org/10.5367/000000006776387150

World Tourism Organization (UNWTO). (2008). Retrieved October 26, 2008, from http://www.worldtourism.org

Yang, C., \& Lu, W. M. (2006). Performance benchmarking for Taiwan's international tourist hotels. Information Systems and Operational Research, 44(3), 229-245.

\section{Copyrights}

Copyright for this article is retained by the author(s), with first publication rights granted to the journal.

This is an open-access article distributed under the terms and conditions of the Creative Commons Attribution license (http://creativecommons.org/licenses/by/3.0/). 